\title{
Aerobic alcohol oxidations mediated by nitric acid
}

\section{Doctoral Thesis}

Author(s):

Aellig, Christof

Publication date:

2013

Permanent link:

https://doi.org/10.3929/ethz-a-009995236

Rights / license:

In Copyright - Non-Commercial Use Permitted 
Diss. ETH No. 21261

\title{
Aerobic Alcohol Oxidations Mediated by Nitric Acid
}

A dissertation submitted to

ETH ZÜRICH

for the degree of

DOCTOR OF SCIENCE

Presented by

\author{
CHRISTOF AELLIG \\ MSc Chemical and Bioengineering, ETH Zürich \\ born on March 22, 1985 \\ citizen of Adelboden (BE)
}

accepted on the recommendation of

Prof. Dr. Ive Hermans

Prof. Dr. Christophe Copéret 


\section{Summary}

The selective oxyfunctionalization of organic substrates plays a very important role in the chemical industry. Despite its industrial relevance the scientific understanding lags behind the current state-of-the-art. Radical-chain autoxidations are a classical example of large-scale technology which is still not completely understood. Nitric acid based oxidations are another example of poorly understood processes of tremendous industrial importance. The production of adipic acid ( $3 \mathrm{Mt} / \mathrm{year}$ ) which is an important building block for the nylon-6,6 synthesis is just one example. One of the intrinsic challenges in this field is the prevention of side or consecutive reactions since the products are most often more reactive than the substrates. Especially the selective oxidation of primary alcohols to the corresponding aldehydes is not an easy task because of the overoxidation to the carboxylic acids. Therefore a profound understanding of the reaction kinetics and thermodynamics are an important prerequisite in order to be able to optimize the selectivity to the desired product.

Chapter 1 presents a mini review of the oxyfunctionalisation of organic substrates, focusing on aerobic alcohol oxidations. Both transition metal based and nitric acid based alcohol oxidations are discussed. Additionally the industrial importance of these transformations is highlighted.

Chapter 2 focuses on the reaction mechanism of the partial aerobic oxidation of benzyl alcohol to benzaldehyde mediated by nitric acid. From this study, it can be concluded that $\mathrm{HNO}_{3}$ is able to start off a chain oxidation of benzyl alcohol, mediated by $(\mathrm{H}) \mathrm{NO}_{\mathrm{x}}$ species; $\mathrm{O}_{2}$ is however the terminal oxidant. A significant increase in chain length, and hence an improved yield, can be achieved at lower temperature, or upon drying of the gas phase. This chain reaction is catalyzed by the solid acid Amberlyst$15^{\circledR}$. Depending on the acid catalyst loading, either the $\mathrm{HNO}_{3}$ or the nitrite decomposition is rate determining; both steps are acid catalyzed. 
In chapter 3 the importance of the acid-catalyzed decomposition of the benzyl nitrite intermediate during the $\mathrm{HNO}_{3}$-mediated aerobic oxidation of benzyl alcohol is corroborated. Nitrite decomposition is identified as the source of $\mathrm{N}_{2} \mathrm{O}$. A linear Hammett plot with a negative slope is obtained that indicates a transition state with reduced electron density. Kinetic isotope effect studies imply that cleavage of the $\mathrm{C}_{\alpha^{-}}$ $\mathrm{H}$ bond is involved in the decisive transition state, and electron withdrawing groups are found to reduce the reactivity of the nitrite significantly. This effect is also reflected in the overall oxidation reaction of the corresponding alcohol, thereby supporting the reaction mechanism.

In chapter 4 a continuous process for the aerobic oxidations of alcohols mediated by $\mathrm{HNO}_{3}$ was developed. A significant increase in the reaction rate and two orders of magnitude in the space-time-yield could be observed for the aerobic oxidation of benzyl alcohol to benzaldehyde, compared to other reactors. Additionally, the activity of the catalyst was maintained over two weeks making the process attractive compared to transition metal catalyzed systems that very often suffer from deactivation and/or low activities. The increased reaction rate can not only be attributed to a higher catalyst-to-substrate ratio in the flow reactor, but also to a longer $\mathrm{HNO}$ chain length, which minimizes both the initial amount of $\mathrm{HNO}_{3}$ required for efficient oxidation, and the production of $\mathrm{N}_{2} \mathrm{O}$. Furthermore, this increased $(\mathrm{H}) \mathrm{NO}_{x}$ selectivity is also accompanied by an increased carbonyl selectivity, due to the decrease in over-oxidation products and the termination of the oxygen shuttle species. The continuous reaction system could successfully be extended to oxidize several aliphatic and non-aliphatic primary and secondary alcohols always showing a high reaction rate and selectivity.

In chapter 5 The continuous aerobic oxidation of different alcohols using a heterogeneous immobilized TEMPO catalyst was examined. High reaction rates, conversions and selectivities could be obtained. The catalyst remained stable over several hours under mild conditions making the process attractive. Due to the high 
reaction rates, only small amounts of $\mathrm{HNO}_{3}$ as co-oxidant have to be used. The system is broadly applicable to a wide range of primary and secondary alcohols, always showing high reaction rates and selectivities. Another advantage of this continuous system is the flexibility of tuning the selectivity in consecutive reactions depending on the application. This can be seen in the case of 5hydroxymethylfurfural oxidation where high yields of either 2,5-diformylfuran or 2,5furandicarboxylic acid can be obtained, depending on the contact time. Additionally, less stable alcohols like lactic acid or prenols could be smoothly oxidized, due to the moderate conditions of only $55^{\circ} \mathrm{C}$ and 5 bar $\mathrm{O}_{2}$. 


\section{Zusammenfassung}

Die selektive Oxyfunktionalisierung von organischen Substraten spielt eine sehr wichtige Rolle in der chemischen Wertschöpfungskette. Trotz der industriellen Relevanz dieser Reaktionen bleibt das wissenschafltiche Verständnis dieser Reaktionen noch limitiert im Vergleich zum neusten Stand der Technik. Ein anderes Beispiel von mangelhaft verstandenen Reaktionen von sehr wichtigem Ausmass in der Industrie sind Oxidationsreaktionen basierend auf Salpetersäure. Ein Beispiel dafür ist die Herstellung von Adipinsäure ( $3 \mathrm{Mt} / \mathrm{Jahr}$ ), welche ein wichtiges Intermediat für die Herstellung von Nylon-6,6 ist. Eine der intrinsischen Herausforderungen ist die Vermeidung von Parallel- und Folgereaktionen, da die Produkte oft reaktiver sind als die Substrate. Vor allem die selektive partielle Oxidation von primären Alkoholen zu den korrespondierenden Aldehyden ist keine einfache Aufgabe, da die Produkte leicht zu den Carbonsäuren überoxidieren. Ein tiefes Verständnis der Reaktionskinetik und Thermodynamik sind deshalb wichtige Voraussetzungen, um die Selektivität des gewünschten Produktes zu erhöhen.

Kaptiel 1 gibt einen kleinen Überblick über Oxyfunktionalisierungen von organischen Substraten mit Fokus auf aeroben Alkoholoxidationen. Dabei werden Übergangsmetall- und Salpetersäurenkatalysierte Alkoholoxidationen diskutiert. Zusätzlich wird die Wichtigkeit dieser Transformationen in der Industrie hervorgehoben.

In Kapitel 2 wird der Fokus auf den Reaktionsmechanismus von der partiellen aeroben Oxidation von Benzylalkohol zu Benzaldehyd mithilfe von $\mathrm{HNO}_{3}$ gelegt. Aus dieser Arbeit kann geschlossen werden, dass $\mathrm{HNO}_{3}$ eine Kettenoxidationsreaktion von Benzylalkohol starten kann, die mithilfe von $(\mathrm{H}) \mathrm{NO}_{x}$ Spezies abläuft, wo aber $\mathrm{O}_{2}$ das terminale Oxidationsmittel ist. Bei tieferer Temperatur oder wenn die Gasphase getrocknet wird, können die Selektivität und die Ausbeute signifikant erhöht werden. Diese Kettenreaktion wird durch die Feststoffsäure Amberlyst- $15^{\circledR}$ katalysiert. In 
Abhängigkeit der Menge an Katalysator, ist in der Reaktion entweder der säurenkatalysierte Zerfall vom Nitritester oder der Zerfall von $\mathrm{HNO}_{3}$ der geschwindigkeitsbestimmende Schritt.

In Kapitel 3 wird die Wichtigkeit des säurenkatalysierten Zerfalls vom Benzylnitritester in der aeroben Alkoholoxidation von Benzylalkohol mithilfe von $\mathrm{HNO}_{3}$ näher erläutert. Der Nitritzerfall wird als Quelle der Bildung von $\mathrm{N}_{2} \mathrm{O}$ identifiziert. Ein linearer Hammett Graph mit einer negativen Steigung wurde erhalten, was auf einen Übergangszustand mit reduzierter Elektronendichte hindeutet. Die Untersuchung vom kinetischen Isotopeneffekt deutet darauf hin, dass die Trennung der $\mathrm{C}_{\alpha}-\mathrm{H}$ Bindung im entscheidenden Überganszustand involviert ist. Elektronegative Gruppen in Paraposition reduzieren die Reaktivität vom Nitrit entscheidend. Dieser Effekt kann auch in der Oxidationsreaktion vom entsprechenden Alkohol beobachtet werden, was den vorgeschlagenen Reaktionsmechanismus stützt.

In Kapitel 4 wird ein kontinuierlicher Prozess für die aerobe Alkoholoxidation mithilfe von $\mathrm{HNO}_{3}$ entwickelt. Dabei konnte ein signifikanter Anstieg der Reaktionsgeschwindigkeit und der spezifischen Produkteleistung im Vergleich zu anderen Reaktoren beobachtet werden. Zusätzlich blieb die Aktivität des Katalysators über zwei Wochen stabil. Die erhöhte Reaktionsgeschwindigkeit kann dabei nicht nur auf das erhöhte Katalysator- zu Substratverhältnis im kontinuierlichen Flussreaktor zurückgeführt werden, aber auch auf eine Kettenverlängerung der HNO Spezies. Dies führt zu einer Reduktion der $\mathrm{N}_{2} \mathrm{O}$ Bildung und der eingesetzten $\mathrm{HNO}_{3}$ Menge, die für eine effiziente Oxidation gebraucht wird. Diese erhöhte $(H) N_{x}$ Selektivät wird durch eine erhöhte Carbonylselektivät begleitet, was durch eine Verringerung der Überoxidation zu den entsprechenden Carbonsäuren zu erklären ist. Dieses kontinuierliche Reaktionssystem konnte erfolgreich auf andere aliphatische und nicht alphatische, primäre und sekundäre Alkohole erweitert 
werden, dabei wurden immer hohe Reaktionsgeschwindigkeiten und Selektivitäten beobachtet.

In Kapitel 5 wird die kontinuierliche aerobe Oxidation von verschiedenen Alkoholen mit einem heterogenen immobilisierten TEMPO Katalysator untersucht. Dabei konnten hohe Reaktionsgeschwindigkeiten, Umsätze und Selektivitäten erhalten werden. Der Katalysator blieb bei milden Reaktionsbedingungen über mehrere Stunden stabil. Aufgrund der hohen Reaktionsgeschwindigkeiten musste nur eine sehr geringe Menge an $\mathrm{HNO}_{3}$ als co-Oxidationsmittel eingesetzt werden. Das System kann auf eine Vielzahl von primären und sekundären Alkoholen angewendet werden. Ein zusätzlicher Vorteil dieses Reaktionssystemes ist die Möglichkeit, die Selektivität von Folgereaktionen entweder in die eine oder andere Richtung zu lenken. Dies kann bei der Oxidation von 5-Hydroxymethylfurfural gesehen werden, wo, je nach Verweilzeit, hohe Ausbeuten von 2,5-Diformylfuran oder 2,5-Furandicarboxylsäure erhalten werden konnten. Zusätzlich konnten auch weniger stabile Alkohole, wie Milchsäure oder Prenole ohne Probleme zu den entsprechenden Carbonylen bei nur $55{ }^{\circ} \mathrm{C}$ und 5 bar $\mathrm{O}_{2}$ oxidiert werden. 